\author{
Aleksandra Szyller \\ Uniwersytet Warszawski \\ szyllerola@gmail.com
}

\title{
Bezrefleksyjna codzienność refleksyjnych uczniów, czyli polska edukacja wezesnoszkolna z podręcznikiem w tle
}

\author{
Summary \\ Non-reflexive everyday life of the reflexive students - \\ Polish early school education with a textbook in the background
}

This article presents my own research results. The research consists of the third-graders' opinions about the textbook role and usefulness in the teaching process and the analysis of children's experiences connected to the educational packets in the school practice. The qualitative data had been gathered trough focus interviews and enriched with the analysis of students' works. As the research shows, the children's negative perception of everyday school life seems to origin in the teachers' admiration to go through the textbooks page by page and students' subjection to the textbooks packets. Everyday work with the textbook forces children to make often anti-developmental tasks and to resign from divergent and creative thinking in favor of acting according to the designated algorithm. The modern school with the textbook on the pedestal is changing into a space with growing restrictions. The creation of independent subjects is giving place to the formation of other-directed individuals, lacking of the ability to think reflective, which is an important change catalyst.

Słowa kluczowe: podręcznik, edukacja wczesnoszkolna, badania partycypacyjne, codzienność, bezrefleksyjność, odtwórczość

Keywords: student's book, early education, participation research, every-day reality, reflectiveness, recreating

\section{Kilka słów o codzienności}

Refleksja nad codziennością zdaje się być pomostem między teorią i praktyką, „odsłania nieznaną, nową rzeczywistość, rzuca nowe spojrzenie na tę już znaną, której się zwykle doświadczało” (Łukasik 2013: 11). Jak pisze Diane Watson: „życie codzienne (...) przyjmujemy bezrefleksyjnie i nie czynimy tematem krytycznych pytań (Watson 2002: 189). W ostatnich latach, prawdopodobnie właśnie ze względu na daleko posunięty brak kontemplacyjności, codzienność coraz częściej staje się przedmiotem ogólnego dyskursu, punktem zainteresowań badaczy. Czym więc jest codzienność? W potocznym rozumieniu termin codzienność można opisać za pomocą takich rzeczowników, jak: samooczywistość, powtarzalność, przyziemność, cykliczność, powszedniość, nawyk i rutyna. Charakteryzu- 
jąc codzienność szkolną uczniów, zaryzykować można użycie bardziej pejoratywnych określeń: automatyzm, bezrefleksyjność i nuda. W literaturze przedmiotu odnajdujemy wiele, wzajemnie dopełniających się definicji tego terminu. Zdaniem Małgorzaty Dzięgielewskiej codzienność jest konstruktem uniwersalnym, czymś, co jest zawsze i wszędzie, posiadającym wymiar materialny, społeczny i symboliczny (Dzięgielewska 1996, Dzięgielewska 2002). Bernhard Waldenfens określa codzienność jako zwykłość, utarty porządek, sferę tego, co konkretne, uchwytne, naoczne, powtarzalne, zamknięte i skrępowane, mówiąc najprościej - przeciwieństwo niecodzienności (Waldenfens 1993). Definicję skonstruowaną przez zestawienie ze sobą antagonizmów proponuje Marian Golka, twierdząc, że codzienność można przeciwstawić odświętności, oficjalności, niezwykłości i wyjątkowości (Golka 2009). Na temporalny charakter codzienności zwraca uwagę Marek Krajewski, wskazując, że „codzienność już przez swoją nazwę sugeruje, iż jest wymierzona w przyszłość, zawiera w sobie bowiem pewność, że nie tylko nastanie ,jutro", ale też będzie ono podobne do „dzisiaj i wczoraj” (Krajewski 2009: 198). Najpełniejszą definicję codzienności wydaje się proponować Piotr Sztompka, wskazując na osiem cech ją charakteryzujących: życie z innymi, powtarzalność zdarzeń, formy rytualne, angażowanie cielesności, lokalizacje w przestrzeni, ramy czasowe, automatyzm i spontaniczność (Sztompka 2008: 24-25).

Tematem niniejszego artykułu będzie codzienność edukacyjna uczniów, pracujących z podręcznikiem w szkole, identyfikowana jako trwała, rutynowa forma cykliczna, wykonywana automatycznie, dzień w dzień według wdrukowanego, bezrefleksyjnego scenariusza, angażująca siły i możliwości dzieci.

\section{Refleksyjni uczniowie w nierefleksyjnej szkole}

Codzienność w odniesieniu do podmiotów jej doświadczających odnosi się do podstawowych kręgów socjalizacyjnych, gdzie priorytetowa okazuje się być rola szkoły, jako jednego z niezbywalnych elementów życia (Ferenz 2003: 19). To tu uczniowie spędzając ponad tysiąc godzin rocznie (Taraszkiewicz 1996), uczestniczą w początkowo nieznanych, szybko oswajanych, cyklicznych rytuałach. „[...] uczeń wchodzi w środowisko szkolne jako początkowo niecodzienne, zaś niecodzienność ta musi zostać poznana, zrozumiana, oswojona, stając się stopniowo zwykła (codzienna), przez swe zrutynizowanie i powtarzalność czynności w niej wykonywanych” (Wysocka, Tomiczek, 2014: 173).

W moich rozważaniach przedmiotem zainteresowania chciałam uczynić szkolną bezrefleksyjną rzeczywistość refleksyjnych uczniów edukacji wczesnoszkolnej, traktując ich jako kompetentnych informatorów, ekspertów własnej codzienności. W powszechnej świadomości istnieje przekonanie, że „małe dzieci mają przede wszystkim słuchać tego, co mówią do nich dorośli, same niewiele mając do powiedzenia” (Zwiernik 2012: 161). Tymczasem najmłodsi mogą stać się wiarygodnym źródłem informującym dorosłych o znaczeniu, jakie mają dla nich sytuacje z ich codziennego życia w szkole (Clark 2005). Za priorytet współczesnej edukacji należałoby dziś uznać słuchanie dzieci i uwzględnienie ich głosu w organizacji placówek edukacyjnych. 
Jak wskazuje Bruner, możemy wyróżnić cztery współcześnie funkcjonujące modele umysłu ucznia: uczeń jako nowicjusz „niewiedzący”, tabula rasa (karta do wypełnienia), uczeń zdolny do rozumowania i refleksji nad swoim myśleniem oraz uczeń „wiedzący” (Filipiak 2011: 110). Wymienione modele zdają się determinować przyjęte sposoby nauczania, charakter relacji występujący pomiędzy dzieckiem i dorosłym. Pierwszy i drugi model umysłu dziecka, gdzie nauczyciel jest ekspertem lub przekazicielem wiedzy, a dziecko biernym jej odbiorcą, wyklucza niejako możliwość prowadzenia badań partycypacyjnych wśród uczniów (ze względu na stawiane założenie o bezrefleksyjności dzieci). Zdecydowanie bliższa mi jest trzecia kategoria modelu umysłu w ujęciu Brunera, przeświadczenie, że najmłodsi okazują się być niezwykle refleksyjnymi praktykami, którzy dokonują namysłu nad tym, co robią, poddają refleksji swoje funkcjonowanie w szkole, analizują doświadczenia, chcą wprowadzać zmiany. Paradoksalnie, jak wskazują wyniki moich badań, refleksyjność uczniów zdaje się obnażać brak refleksyjności osób dorosłych, odpowiedzialnych za kształt i jakość polskiej edukacji.

\section{Podręcznik szkolny jako codzienność uczniów klas początkowych}

Szkolna codzienność dzisiejszych uczniów ogniskuje się wokół pracy z pakietem edukacyjnym. Hasło OTWÓRZCIE PODRĘCZNIKI, będące egzemplifikacją tzw. biernego startu, stało się nieodłącznym i znienawidzonym przez uczniów, codziennym elementem niemal każdej lekcji (Zalewska 2008). O niegasnącej roli i popularności „elementarza” stosowanego jako podstawowa pomoc dydaktyczna może świadczyć fakt, że stał się on tematem społecznej i politycznej dyskusji. „Podręcznik nabrał więc dodatkowego znaczenia jako towar, jako źródło zysku uwzględniane w strategiach wydawniczych, w rozgrywkach politycznych dorosłych i jako narzędzie pozyskiwania wyborców".

Przed reformą podręcznikową z 2014 na etapie edukacji wczesnoszkolnej mieliśmy do wyboru ponad czterdzieści tytułów. Łączna liczba podręczników dla wszystkich etapów kształcenia liczyła kilkaset zestawów (Chomczyńska-Rubacha 2011: 8). Dziś po wdrożeniu reformy podręcznikowej, wyparciu zróżnicowanej oferty przez darmowy, stworzony przez MEN „Nasz Elementarz”, ponownie powracamy do szerszego wyboru z jedenastu tytułów zatwierdzonych na etapie edukacji wczesnoszkolnej do użytku szkolnego.

W polskiej edukacji ciągle wydaje się dominować dogmat prorozwojowego potencjału podręcznika - niezawodnego środka realizacji założeń programowych (Zalewska 2008). Wśród dorosłych panuje stereotyp, że wiedza i umiejętności dzieci wykazują pozytywną korelację z liczbą wypełnionych stron i rozwiązanych zadań z pakietu edukacyjnego (Zimny 1995). Tym samym osoby odpowiedzialne za kształt oświaty w Polsce nie są w stanie wyobrazić sobie edukacji bez podręcznika. Zgodnie z wynikami badań Małgorzaty Drost tylko $11 \%$ nauczycieli deklaruje możliwość rezygnacji z tego środka dydaktycznego w edukacji początkowej (Drost 2000), 68\% rodziców nie akceptuje selektywnej pracy z „elementarzem”, możliwości rezygnacji z niektórych zadań, tematów (Zbróg 2005). 
Mimo że w polskim dyskursie naukowym pojawiają się coraz częściej wyniki badań dotyczące pakietów edukacyjnych, widoczny jest brak aktualnych i kompleksowych analiz koncentrujących się na jakości pakietów edukacyjnych dla edukacji wczesnoszkolnej, ich roli w procesie nauczania, efektów codziennie uprawianej kartomanii. Zdecydowanie większym zainteresowaniem badaczy cieszą się podręczniki do edukacji przedmiotowej a podjęte badania skupiają się raczej na warstwie socjalizacyjnej, nie merytoryczno-dydaktycznej książek do nauki ${ }^{1}$.

\section{Wyniki badań własnych}

Jak wygląda szkolna codzienność uczniów edukacji wczesnoszkolnej? Jak często korzystają z podręcznika? W jaki sposób odbywa się ich codzienna praca z pakietem edukacyjnym? Co zostaje im odebrane, a co zyskują pracując z takim źródłem? Odpowiedzi na te i inne pytania poszukiwałam wśród trzecioklasistów, refleksyjnych, krytycznych i najważniejszych uczestników procesu nauczania i uczenia się, odbiorców podręcznikowych treści. Podmiotów, których „stłumiony głos” (Hardman 1973) w badaniach dotyczących stanu edukacji w Polsce, w przeciwieństwie do krajów zachodnich, jest ciągle marginalizowany lub całkowicie ignorowany.

W opisywanych w niniejszym artykule badaniach brali udział trzecioklasiści. Wywiady przeprowadziłam wśród dwustu sześćdziesięciu czterech uczniów w dwunastu klasach trzecich wybranych w drodze doboru celowego z dwunastu szkół podstawowych w województwie mazowieckim. Wykorzystałam tu m.in. technikę wywiadów fokusowych. Paradygmat konstruktywistyczny, badanie dziecięcego sposobu widzenia świata został tu przeciwstawiony antropologicznej perspektywie skoncentrowanej na świecie dorosłych (Gara 2016). Poznawanie tego, co się dzieje w naturalnych warunkach codziennego życia uczniów, odbywało się więc poprzez intencjonalne badania zogniskowane na pracy dzieci z podręcznikiem (Czerepaniak-Walczak 2010).

\section{Uświęcony pakiet edukacyjny jako ogniwo każdej lekcji}

Zdecydowana większość trzecioklasistów uważa, że ich szkolna codzienność koncentruje się wokół pracy z podręcznikiem jako nieodłącznym środku dydaktycznym stosowanym niemal na każdej lekcji.

Bardzo rzadko mamy takie lekcje (bez podręczników - przypis autorki).

Codziennie pracujemy z kilkoma książkami. Jak mamy dwie lekcje matematyki i dwie polskiego to cały czas.

\footnotetext{
1 Najbardziej znaną badaczką zajmującą się analizą informacyjnej funkcji podręcznika do edukacji wczesnoszkolnej jest Anna Jurek. Nacisk na socjalizacyjny potencjał książek do nauki dla najmłodszych szczególnie widoczny jest w pracach Moniki Wiśniewskiej-Kin i Ewy Zalewskiej. Obie są autorkami publikacji osadzonych w nurcie analityczno-dyskursywnym podręczników. Analizę podręczników dla wyższych etapów edukacji można znaleźć w publikacjach Agnieszki Rypel i Violetty Kopińskiej.
} 
Na każdej lekcji korzystamy z elementarza.

Prawie zawsze. Chyba, że piszemy w zeszycie, to wtedy do nich nie zaglądamy.

Tylko na w-fie nie (pracujemy z podręcznikiem - przypis autorki).

Pani przyszła i to są nasze pierwsze zajęcia bez podręcznika. Niech Pani zostanie.

Nie, jak naszej Pani nie ma to, nie pracujemy.

Uczynienie podręcznika podstawową pomocą dydaktyczną spotyka się z dezaprobatą ze strony dzieci. Brak wykorzystywania pakietów edukacyjnych występuje jedynie na zajęciach, które ze względu na swą formułę albo zupełnie wykluczają użytkowanie podręcznika (w-f, wyjścia na basen, klasówki), albo zdecydowanie nie powinny odbywać się w oparciu o ten środek dydaktyczny (wycieczki, prace plastyczne, zajęcia z użyciem komputera, zajęcia organizacyjne, godziny wychowawcze). Okazją do zorganizowania lekcji poza podręcznikiem są także zastępstwa.

Kiedy jeszcze nie korzystacie z podręcznika? Kiedy wychodzimy na basen, kiedy są weekendy.

Jak są kartkówki, klasówki. Sprawdzian. A poza klasówkami? To zawsze pracujemy w podręczniku.

Kiedy chodzimy na występy, nie wyciągamy podręczników

Tak, jak jakiś gość do nas przychodzi.

Jak idziemy do lasu i sprzątamy śmieci albo zbieramy grzyby. I zielona noc

Zawsze z podręcznikiem, no chyba, że piszemy w zeszytach. I jeździmy na wycieczki, ale nie było w ogóle ostatnio.

Mimo nielicznych i krótkich epizodów pracy pozapodręcznikowej, do których dzieci odnoszą się z ogromną aprobatą, można stwierdzić, że codzienna praca $\mathrm{z}$,elementarzem" odbywa się przy uprawianiu tzw. kartomanii. Tylko pojedynczy nauczyciele są w stanie pracować z podręcznikiem w sposób selektywny, omijając tematy powierzchowne, niewprowadzające interesujących treści, infantylne, zawierające błędy metodyczne i merytoryczne, niedopasowane do wiedzy i możliwości dzieci (za infantylne, za trudne). Trzecioklasiści akceptują takie podejście, uważając je za słuszne. Okazują głębokie zaniepokojenie faktem, że taki sposób prowadzenia zajęć jest w szkole rzadkością, epizodem w ich codziennym życiu.

Niektórych „tematów” nasza Pani w ogóle nie robi. Czasami zostawiamy puste strony.

Nie wypełniamy wszystkiego. Omijamy, bo te zadania są głupie.

Tak i niektóre strony wyrwać. Ominąć. Czasami omijamy, ale za mało.

Czasami coś skreślamy, bo jest za trudne, albo Pani nie chce tego robić. Tak, może Pani uznała, że woli zamiast tego, zrobić co innego. Właśnie, właśnie, coś lepszego.

Konkludując, można stwierdzić, że szkolna codzienność uczniów ogniskuje się wokół wykorzystania podręcznika użytkowanego niemal na każdych zajęciach i wypełnianego w większości od deski do deski. Konsekwencją takiego stanu rzeczy jest skoncentrowanie 
procesu nauczania wokół określonych algorytmów, powielających się na zajęciach aktywności, które uczniowie uważają za bezrefleksyjne, bezsensowne i uwsteczniające.

\section{Znienawidzone, codzienne aktywności}

Polscy uczniowie zdają sobie sprawę, że codzienna praca z pakietem zmusza ich do realizacji zadań, które dalekie są od prorozwojowych. Do najbardziej znienawidzonych przez uczniów aktywności, które implikowane są przez wyznawany przez nauczycieli ,podręcznikocentryzm" i które stanowią codzienność na zajęciach szkolnych, należą wielokrotnie powtarzane, odtwórcze, zbyt proste, narzucające ograniczenia i mechaniczne wykonywanie działania. Infantylizm treści w podręcznikach doprowadza do obniżania potencjału dzieci, zmuszając je niejako do codziennego stosowania rozmaitych strategii przetrwania i nieujawniania tego, co już wiedzą. Jedną z konsekwencji codziennego użytkowania podręczników okazuje się być także nadużywany przez nauczycieli werbalizm oraz nadmiar prac domowych, polegających na uzupełnianiu w pakietach edukacyjnych tego, na co nie starczyło czasu na zajęciach szkolnych. Wszystko to stanowi codzienny, smutny świat uczniów.

Codzienną pracę dzieci z pakietami można określić jako czas bezrefleksyjny i bezproduktywny. Uczniowie bardzo często wskazują na brak różnorodności, wielokrotne powielanie w podręcznikach zadań doskonalących te same umiejętności. Konieczność całościowej pracy z pakietem, bez możliwości ominięcia tego co multiplikowane, doprowadza do nudy i braku czasu na zdecydowanie bardziej wartościowe zadania.

Za dużo jest tych działań na jednej stronie, a my robimy po kilkaset. I nie ma czasu na inne rzeczy. Na rysowanie. Nie rysujecie? Nie, bardzo rzadko. Chcielibyśmy więcej.

Cała strona tabliczki mnożenia. To było okropne. To było za łatwe i nudne. Po co aż tyle tego było. Powinno być po jednym przykładzie a nie po sto, jak już każdy wie, o co chodzi. Tego jest za dużo.

My to już wiemy, a dalej musimy robić to samo. Tak i tak w kółko.

I z matematyki jest tak, że na górze jest zadanie i dwie strony na ten sam temat, dotyczące tego samego zadania. Tego jest za dużo.

Wśród innych następstw codziennego stosowania pakietów można wyróżnić deprecjonowanie doświadczeń i wiedzy osobistej dzieci, naukę określonych treści zgodnie z rozkładem materiału, a nie aktualną rzeczywistą wiedzą i zainteresowaniami dzieci. Oderwanie szkoły od życia, brak czasu i miejsca na omawianie w szkole tego, co interesuje uczniów, jest bliskie ich doświadczeniom i możliwościom niezwykle martwi dzieci.

Nie mamy jeszcze dzielenia, a bardzo chcemy dzielenie. Wiemy o co chodzi w dzieleniu, ale nie uczymy się tego. Dlaczego? Bo Pani nas jakoś tak uczy inaczej, woli żebyśmy dzielenie zostawili na trzeciej klasy koniec. A ja bym chciała już. 
Jak Polska wygrała w siatkówkę, to w szkolę się o tym nie rozmawiało. Pani mówi, że to są tematy do domu. Do domu? Tak, na rozmowy nie w szkole. I zgadzacie się z tym? Nie. Bo co mnie obchodzi jakiś chleb w podręczniku, jak tu Polska wygrywa. Hip hip hura.

Najbardziej znienawidzonym przez uczniów zadaniem konwergencyjnym, będącym ich codziennym udziałem, jest obliczanie działań z narzuceniem sposobu ich rozwiązania. Dzieci nie rozumieją powodu, dla którego nie mogą wykorzystywać własnych strategii dojścia do rozwiązania. Apelują o uwzględnienie ich intelektualnego potencjału.

Ja chciałem powiedzieć, że słabe jest rozpisywanie, bo bardzo dużo osób się na to skarży. Nienawidzę rozpisywać. Świat to nie jest przecież niewola. II wojna światowa minęła.

Po co, jak ja naprzód znam wynik.

Ja bym wołała nie robić rzeczy, które mnie zniechęcają i nie chcę robić, ich nie lubię. A co was zniechęca w tym podręczniku? Rozpisywanie.

Po co to robimy? Ja chciałam napisać normalnie, a tata mówi, że wszystko mam dobrze, ale mam to rozpisać. Szkoda czasu na wszystko.

Mi też rozpisywanie się nie podoba. Wolałbym obliczyć w pamięci, a tak siedzę nad pracą domową. Bez sensu, bo jestem bardzo dobry z matematyki i raczej bym go znał.

Umiemy w pamięci. Nie jesteśmy głupi.

Ja lubię: Oblicz dowolnym sposobem.

Czasami mamy dwie strony rozpisywania, jednym sposobem napisanym w przykładzie. I to jest masakra. Ja np. szybko liczę i wolę w pamięci.

Ja wolę, jak można wszystkimi możliwymi, a nie można.

Obok konieczności rozpisywania działań, drugą w kolejności codzienną i najbardziej krytykowaną przez uczniów aktywnością jest mechaniczne pisanie i przepisywanie, występujące zarówno na matematyce, jak i na języku polskim. W przypadku treści językowych dotyczy także dłuższych form wypowiedzi, np. wierszy, opowiadań. Sensowność i celowość wykonywania takich działań pozostaje dla dzieci zagadką. Chcą działać same, tworzyć własne teksty.

Ja mam potąd pisania. Po czubki głów.

To pisanie mnie już wykańcza.

Można sobie na te pytania odpowiedzieć w myśli. Ciągle coś uzupełniamy.

Albo przepisywanie całej strony. Trzeba pisać i pisać to jest bez sensu.

Ręka mnie boli. Tak, ja też musze rozluźniać. Pierwsza strona, druga, setna.

Ja nienawidzę przepisywania $\mathrm{z}$ tablicy. Wolałbym sam.

Ja nie lubię zadań, gdzie trzeba przepisywać z kilku ćwiczeń do jednego i to nie ma sensu. Bo tekst już przecież jest i szkoda czasu. To jest nudne. Blee.

Problemem bardzo często zgłaszanym przez dzieci jest nadmierny werbalizm uprawiany na codziennych lekcjach. Brak pokazywania rzeczy i zjawisk na filmach, w rze- 
czywistości, jest niezrozumiały dla uczniów posiadających w klasie dostęp do Internetu. Ograniczanie się w nauczaniu do podręcznika i wykładu uniemożliwia całościowe, polisensoryczne poznanie omawianych obiektów.

Pani od religii też za dużo gada. Tak i nam się chce spać. My byśmy woleli coś pooglądać. Ja bym chciała, że jak już mówimy o jakimś kraju, żeby Pani nam coś pokazywała na tablicy albo coś, a tak to my tylko wiemy, co w książkach było, ale nic nam więcej nie pokazuje tylko mówi.

Dzieci są zdania, że praca z podręcznikiem powinna zejść na dalszy plan, dzięki czemu w szkole znalazłby się czas na realizację innych, znacznie bardziej kreatywnych i zaniedbywanych do tej pory aktywności: eksperymentów i obserwacji oraz gier dydaktycznych, zajęć artystycznych (muzyka, plastyka, zajęcia techniczne), zajęć ogólnorozwojowych (w-f) i zajęć komputerowych. U źródła wszystkich wyżej wymienionych błędów i zaniedbań w nauczaniu stoi zdaniem uczniów uświęcony podręcznik.

My w ogóle nie robimy eksperymentów,

Na przyrodzie nie mamy doświadczeń, np. jakiś wybuchów. To byłoby super.

Dlaczego my w ogóle takich rzeczy nie robimy? Bo my na nic nie mamy czasu. Tylko podręcznik i podręcznik.

Plastyka jest po prostu raz na dziesięć lekcji. Powinna być częściej.

Ja lubię na kartce rysować, a nie wszystko w podręczniku.

Piosenkę śpiewaliśmy raz. (...) bo nigdy nie ma na to czasu.

A teraz my nic nie robimy muzycznego.

My w ogóle nie mamy muzyki.

Ja bym wolała muzykę bez podręcznika.

Nie mamy w ogóle WF-u". Nie zawsze go robimy. Mamy czasami inne zajęcia, które nadrabiamy.

\section{Konkluzje}

Refleksyjne myślenie o edukacji oznacza myślenie krytyczne, systematyczne i kreatywne (Fish, Teinn 1997). Takie też wydają się być rozważania uczniów edukacji wczesnoszkolnej. Cechuje je krytycyzm, zdolności analityczne, otwartość umysłowa i wrażliwość poznawcza. Wszystko to, co jest podstawą refleksyjności (Tickle 1994). Codzienność życia w szkole postrzegana jest przez dzieci krytycznie. Opisując ją, używają przymiotników o wydźwięku negatywnym - nudna, jałowa, bezsensowna i niesatysfakcjonujaca. Frustracja, bierność, poczucie bezradności, odtwórczości wykonywanych zadań zdają się mieć źródło w uprawianej przez nauczycieli kartomanii i podporządkowaniu codzienności szkolnej podręcznikowym pakietom. Współczesna szkoła z podręcznikiem „w roli głównej” zamiast przygotować człowieka krytycznie myślącego, zdolnego do życia w ponowoczesnym świecie, uczącego się przez rozwiązywanie problemów, przekraczają- 
cego granice, kreuje niemal identyczne, konformistyczne podmioty, zewnętrznosterowne jednostki nauczane wykonywać te same, mechaniczne czynności, dostosowując się do tego, co wymagane. W rezultacie takich działań przestrzeń szkoły staje się przestrzenią nasilających się lęków i ograniczeń (Bulla 2009).

Perspektywą podstawową w ocenie jakości funkcjonowania codzienności szkoły mogłaby stać się perspektywa uczniów, których rozwój jest celem podstawowym, niemożliwym do zrealizowania przy istnieniu tak negatywnych postaw, wykazywanych przez dzieci. Pajdocentryzm w edukacji ustępuje dziś miejsca podręcznikocentryzmowi. Zawartość pakietów edukacyjnych stosowanych codziennie, bezkrytycznie i bezrefleksyjnie, przesądza o przebiegu procesu kształcenia. Książka do nauki, determinująca niemal każdy krok dziecka na zajęciach, jest jedną z przyczyn zniechęcenia i demotywowania dzieci do ucznia się. Pomoc stworzona do usprawniania procesu nauczania stała się zniewoleniem.

Praca z podręcznikiem w kontekście codzienności jest swoistym rytuałem, powtarzającą się bezrefleksyjną procedurą z widocznymi elementami przemocy i teatralizacji. Wykonywanie zadań rutynowych nie wymaga stosowania podejścia refleksyjnego (Perkowska 2013). Refleksyjne dzieci pozbawiane są więc możliwości doskonalenia refleksyjnego myślenia, będącego największym katalizatorem zmian. Jak długo jeszcze refleksyjni uczniowie będą w stanie się bronić? Jakie jest panaceum na zmianę szkolnej codzienność uczniów?

A jakby codzienność zmienić w niecodzienność, jakby jutro, które nastanie było odmienne od dzisiaj i wczoraj? Wydaje się, że tego właśnie chciałyby dzieci. Dopóki ich głos nie będzie jednak uwzględniony, póki nauczyciele mający najlepszą pozycję do tego, by słuchać swoich uczniów (Zwiernik 2012) nie otworzą się na ich opinie, dopóty codzienność naszych uczniów będzie ciągle tylko codziennością, a każdy następny dzień w szkole będzie przypominał dzień wczorajszy i zbliżający się dzień jutrzejszy z doprowadzającym do regresu podręcznikiem w tle.

\section{Literatura}

Bulla B. (2009), Preferowane przez uczniów sposoby radzenia sobie z lękiem. „Forum Nauczycieli”, $1(32)$.

Clark A. (2005), Talking and listening to children. W: W. Dudek (red.), Children's spaces. Oxford, Architectural Press.

Czerepaniak-Walczak M. (2010), Emancypacja w codzienności i przez codzienność. Egzemplifikacje edukacyjne. W: M. Czerepaniak-Walczak, M. Dudzikowa (red.), Wychowanie. Pojęcia. Procesy. Konteksty. T. 5, Codzienność w szkole. Szkoła w codzienności. Gdańsk, GWP.

Chomczyńska-Rubacha M. (2011), Wstęp. W: M. Chomczyńska-Rubacha (red.), Podręczniki i poradniki. Konteksty, dyskursy, perspektywy. Kraków, Oficyna Wydawnicza IMPULS.

Drost M. (2000), Konkurencyjność podręczników w kształceniu wczesnoszkolnym. W: W. Puślecki (red.), Kształcenie wczesnoszkolne na przełomie tysiacleci. Warszawa, PAN Komitet Nauk Pedagogicznych, Oficyna Wydawniczo-Poligraficzna „ADAM”.

Dzięgielewska M. (1996), Kultura dnia codziennego a oświata dorosłych. „Edukacja Dorosłych”, 4. 
Dzięgielewska M. (2002), Teoria życia codziennego - poszukiwanie znaczeń. W: A. RadziewiczWinnicki (red.), Edukacja a życie codzienne. T. 1, Katowice, Wydawnictwo UŚ.

Ferenz K. (2003), Szkoła w świecie codzienności dziecka. „Rocznik Lubuski”, t. 29, cz. 2. Dziecko w codzienności szkolnej pod red. K. Ferenz.

Filipiak E. (2011), Z Wygotskim i Brunerem w tle. Stownik pojęć kluczowych. Bydgoszcz, Wydawnictwo UKW.

Fish D., Teinn S. (1997), Quality Clinical Supervision in the Health Professions: Principled Approaches to Practice. Oxford, Butterworth Heinemann

Gara J., Świat życia codziennego jako źródto wiedzy pedagogicznej. http://cejsh.icm.edu.pl/cejsh/ element/bwmeta1.element.desklight-f2bbd5f7-dd24-4aae-bb31-92d3d995e2c0/c/Jaroslaw_ Gara_Swiat_zycia_codziennego_jako_zrodlo_wiedzy_pedagogicznej.pdf (25.10.2016).

Golka M. (2009), Czy jeszcze istnieje nie-codzienność? W: M. Bogunia-Borowska (red.), Barwy codzienności. Analiza socjologiczna. Warszawa, Wydawnictwo Naukowe Scholar.

Hardman C. (1973), Can there be an anthropology of children? "Journal of the Anthropological Society of Oxford", 4 (1).

Jurek A. (2012), Metody nauki czytania i pisania z perspektywy trudności uczniów. Gdańsk, Wydawnictwo Harmonia.

Kopińska V. (2017), Edukacja obywatelska w szkole. Krytyczna analiza dyskursu podręczników szkolnych. Toruń, Wydawnictwo Naukowe UMK.

Krajewski M. (2009), Dzisiaj jak wczoraj, jutro jak dziś. Codzienność, przedmioty i reżimy podtrzymujące. W: M. Bogunia-Borowska (red), Barwy codzienności. Analiza socjologiczna. Warszawa, Wydawnictwo Naukowe Scholar

Łukasik J.M. (2013), Doświadczanie życia codziennego. Narracje nauczycielek na przełomie życia. Kraków, Oficyna Wydawnicza IMPULS.

Perkowska-Klejman A. (2013), Modele refleksyjnego uczenia się. „Teraźniejszość - Człowiek Edukacja”, 1 (161).

Rypel A. (2012), Ideologiczny wymiar dyskursu edukacyjnego na przykładzie podręczników języka polskiego z lat 1918-2010. Bydgoszcz, Wydawnictwo UKW.

Sztompka P. (2008), Życie codzienne - temat najnowszej socjologii. W: P. Sztompka, M. Bogunia-Borowska (red.), Socjologia codzienności. Kraków, Wydawnictwo ZNAK.

Taraszkiewicz M. (1996), Jak uczyć lepiej? Czyli refleksyjny praktyk w działaniu. Warszawa, CODN. Tickle L. (1994), The Induction of New Teachers: Reflective Professional Practice. Castell.

Waldenfens B. (1993), Pogardzona Doxa. Husserl i trwająy kryzys zachodniego rozumu. W: Z. Krasnodębski, K. Nellsen (red.), Świat przeżywany. Warszawa, PIW.

Watson D. (2002), Home from home: the Pub and everyday life. W: T. Bennett, D. Watson (ends.), Understanding Everyday Life. Oxford, Blackwell.

Wiśniewska-Kin M. (2013), Dominacja a wyzwolenie. Wczesnoszkolny dyskurs podręcznikowy i dziecięcy. Łódź, Wydawnictwo UŁ.

Wysocka E., Tomiczek K. (2014), Szkoła jako środowisko życia i codzienność ucznia - analiza teoretyczna i empiryczne egzemplifikacje percepcji i sposobu wartościowania szkoły przez uczniów. „Przegląd Pedagogiczny”, 1 (20).

Zalewska E. (2008), Obraz świata w podręcznikach do klas I-III a twórcze postawy uczniów. W: E. Szatan E., D. Bronk (red.), Gdyby Einstein wspótcześnie chodzit do szkoły. Dziecko i twórczość w pedagogice wczesnoszkolnej. Gdańsk, Wydawnictwo UG. 
Zbróg Z. (2005) Wybrane założenia Podstawy programowej a praktyka szkolna. W: Z. Ratajka (red.), Uczeń we współczesnej szkole. Problemy reformy edukacji wczesnoszkolnej. Kielce, Wydawnictwo Akademii Świętokrzyskiej.

Zimny Z. (red.) (1995), Pomiar dydaktyczny jako instrument doskonalenia procesu kształcenia (na przyktadzie nauczania poczatkowego matematyki). Częstochowa, Wydawnictwo WSP.

Zwiernik J. (2012), Podejście mozaikowe w badaniu doświadczania przez dzieci życia codziennego w instytucjach wczesnej opieki i edukacji. „Przegląd Badań Edukacyjnych”, 2 (15). 